\title{
Diels-Alder Cycloadditions of 2(1H)-Quinolones Having an Electron- Withdrawing Group at the 3-Position Acting as Dienophiles with Dienes
}

\author{
Reiko Fujita, ${ }^{*, a}$ Kazuhiro Watanabe, ${ }^{a}$ Toshiteru Yoshisuji, ${ }^{a}$ Chizuko Kabuto, ${ }^{b}$ \\ Hisao MATSUZAKI, ${ }^{a}$ and Hiroshi HoNGO ${ }^{a}$ \\ Tohoku Pharmaceutical University, ${ }^{a}$ 4-4-1 Komastushima, Aoba-ku, Sendai 981-8558, Japan and Department of \\ Chemistry, Faculty of Science, Tohoku University, ${ }^{b}$ Aobayama, Sendai, 980-8578, Japan. \\ Received March 12, 2001; accepted May 1, 2001
}

\begin{abstract}
Diels-Alder cycloadditions of $2(1 \mathrm{H})$-quinolones having an electron-withdrawing group at the 3-position with alkyl- and silyloxy-1,3-butadienes $(2 a, b)$ were carried out to give phenanthridones richly functionalized regio- or stereoselectively under conditions of atmospheric and high pressure. Furthermore, regioselectivity and chemoselectivity of 3-substituted $2(1 \mathrm{H})$-quinolones to $2 \mathrm{a}$, b were examined using MO calculation.
\end{abstract}

Key words 3-substituted 2(1H)-quinolone; Diels-Alder cycloaddition; regioselectivity; chemoselectivity; electron-withdrawing group; MO calculation

$2(1 H)$-Quinolones are aromatic and there are many reports of substitution reactions. ${ }^{1)}$ Recently, Nakagawa and co-workers reported the first example of a Diels-Alder (DA) reaction of 1-methoxycarbonyl-3-phenylthio-2(1H)-quinolone with 2silyloxydiene in the presence of Lewis acid gave the intermediate for the Dynemisine A core (a marine alkaloid) in 60$70 \%$ yield. The above thermal reactions with 2 -silyloxydiene or Danishefsky diene were unsuccessful. ${ }^{2)}$ The phenanthridone skeleton aromatized or hydrogenated is commonly found in many alkaloids ${ }^{3)}$ of Amarylidaceae. Therefore, phenanthridones richly functionalized would be expected to be potentially valuable synthetic intermediates, and to possess interesting biological activities. ${ }^{3)}$ We have also reported the synthesis of phenanthridones richly functionalized using DA cycloadditions of 2(1H)-quinolones having an electronwithdrawing group at the 4-position. ${ }^{4)}$ It is considered that cycloadditions of 3-substituted $2(1 H)$-quinolones, a moiety acting as a dienophile give phenanthridones functionalized at different positions from those resulting from the DA cycloaddition of 4-substituted 2(1H)-quinolones. In this paper, we wish to report the synthesis of phenanthridones by uncatalyzed and thermal DA cycloadditions of 1-methyl-2(1H)quinolones having an electron-withdrawing group at the 3position with alkyl- and silyloxy-1,3-butadienes under atmospheric and high pressure (AP and $\mathrm{HP}^{5)}$ ) conditions.

DA Cycloaddition Firstly, DA cycloadditions of 1methyl-2(1H)-quinolones having an electron-withdrawing group [such as methoxycarbonyl- (1a) ${ }^{6}{ }^{6}$ cyano- (1b) ${ }^{7)}$ acetyl- (1c), benzoyl- (1d) ${ }^{1, e)}$ formyl- $(\mathbf{1 e}){ }^{8)}$ and nitro$\left.(\mathbf{1 f}, \mathbf{g}),{ }^{9}{ }^{9}\right]$ at the 3-position with 2,3-dimethyl-1,3-butadiene (2a) were examined under AP conditions as shown in Table 1 and Chart 1 . The reactions of $\mathbf{1 a}-\mathbf{d}$ with a symmetric diene (2a) gave stereoselectively functionalized phenanthridones $(\mathbf{3 a}-\mathbf{c}, \mathbf{e}$, entries $1,3,5,7)$ at $180^{\circ} \mathrm{C}$ in moderate yields, but that of $\mathbf{1 d}$ afforded the adduct (3d, entry 6) in poor yield. Upon treatment with diisobutylaluminum hydride (DIBAL), the ester carbonyl group in 3a was reduced to the hydroxymethyl group i.e. 4 . The same reactions of $1 \mathrm{f}$ at $160^{\circ} \mathrm{C}$ produced the cis-adduct (3f, entry 8 ) in $46 \%$ yield stereoselectively, and at $180^{\circ} \mathrm{C}$ gave a new product (5a, entry 9) aromatized by elimination of $\mathrm{HNO}_{2}$ and dehydrogenation in $95 \%$ yield. Similarly, the reaction of $1 \mathrm{~g}$ at $180^{\circ} \mathrm{C}$ (neat) afforded the cis-adduct ( $\mathbf{3 g}$, entry 10) in $94 \%$ yield and additional heating of $\mathbf{3 g}$ at $180^{\circ} \mathrm{C}$ for $2 \mathrm{~d}$ in $o$-xylene gave the aromatized product $(\mathbf{5 b})$ in $64 \%$ yield. HP-DA cycloadditions ${ }^{5)}$ of 1a, b with 2 a at $120^{\circ} \mathrm{C}$ for $2 \mathrm{~d}$ afforded stereoselectively the cis-adducts [3a (51\%), entry 2 ; 3b (7\%), entry 4$]$ with the recovery of the starting material.

Furthermore, cycloadditions of $\mathbf{1 a}, \mathbf{b}, \mathbf{e}, \mathbf{f}$ with Danishefsky's diene (2b) were attempted under AP and HP conditions (Table 2, Chart 2). The reaction of $\mathbf{1 a}$ with unsymmetric $\mathbf{2 b}$ was carried out at $180^{\circ} \mathrm{C}$ for $4 \mathrm{~d}$, followed by trifluoroacetic acid (TFA) work-up to give the cis-enone adduct (6a, entry 1) in $93 \%$ yield, regio- and stereoselectively. Upon treatment with water, the above reaction mixture afforded regio- and stereoselectively the cis-methoxy adduct [7a (91\%), entry 2] only. Under HP condition $\left(10 \mathrm{kbar}, 90^{\circ} \mathrm{C}\right)$, the reaction of $\mathbf{1 a}$ with $\mathbf{2 b}$ afforded the cis-enone adduct [6a (62\%), entry 3] and the new cis-methoxy adduct [8a (24\%), entry 3]. The above reaction mixture was treated with water to give a mixture [6a (32\%), 7a (trace), 8a (40\%), entry 4]. Moreover, the reaction of $\mathbf{1 b}$ with $\mathbf{2 b}$ under AP condition afforded only the cis-enone adduct [6b (98\%), entry 5], followed by refluxing with TFA in chloroform. The above reaction mixture was worked up with TFA at room temperature to give $\mathbf{6 b}(66 \%)$, the cis-methoxy adduct (7b, 9\%), and the trans-methoxy adduct [ $\mathbf{8 b}(9 \%)$, entry 6$]$. On the other hand, the HP reaction of $\mathbf{1 b}$ with $\mathbf{2 b}$ afforded mixture [6b (4\%), $7 \mathbf{b}(9 \%), \mathbf{8 b}$ (66\%), entry 7]. Conversion of the methoxy adduct (7a) to 6a using TFA proceeded smoothly, in order to reduce the steric hindrance between the methoxy and the ester groups, in $97 \%$ yield. On the other hand, conversion of the cismethoxy adduct (8a) to 6a proceeded more slowly than 7a in 97\% yield. Similarly, treatment of the cis-methoxy adduct $(7 \mathbf{b}, \mathbf{8 b})$ with TFA gave $\mathbf{6 b}$ in $79 \%$ and $68 \%$ yields, respectively. As a result, 7a and 8a were isomeric with each other relating to the stereochemistry of the methoxy group and, in addition, $\mathbf{7 b}$ and $\mathbf{8 b}$ were also isomeric. Furthermore, the reaction of $\mathbf{1 e}$ with $\mathbf{2 b}$ produced chemoselectively the hetero DA adduct (9, entry 8$)$ in $71 \%$ yield, resulting from 1,4 -addition of the formyl group to $\mathbf{2 b} .{ }^{10)}$ DA cycloaddition of $\mathbf{1 f}$ with 2b gave only the aromatic product [10a (40\%), entry 9] which was the form favored by enolization of the enone product (10b), because of the important stability associated 


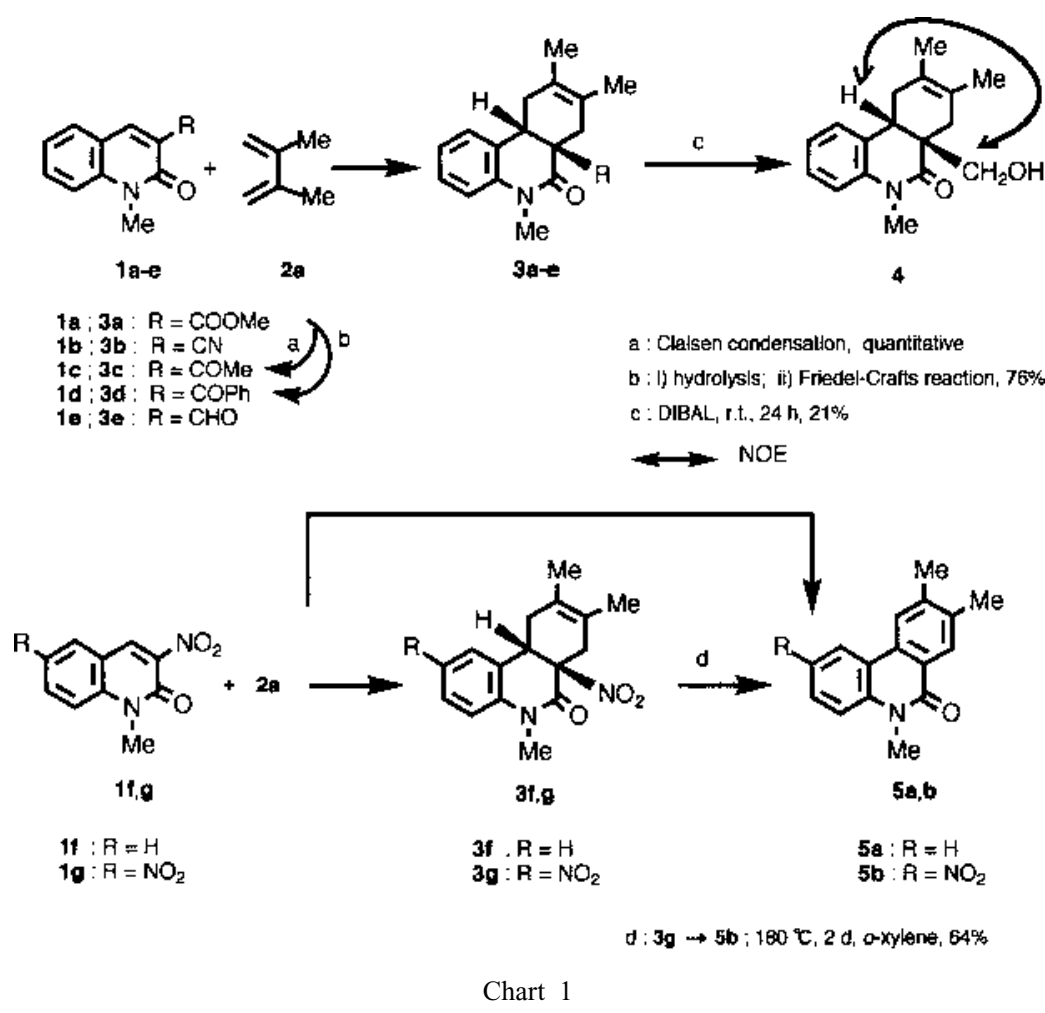

Table 1. DA Cycloadditions of $\mathbf{1 a}-\mathbf{g}$ with $\mathbf{2 a}$

\begin{tabular}{|c|c|c|c|c|c|c|c|}
\hline Entry & Substrate & Temp. $\left({ }^{\circ} \mathrm{C}\right)$ & Time (d) & Solvent & Pressure (kbar) & Adduct & Yield (\%) \\
\hline 1 & $1 \mathrm{a}$ & 180 & 3 & $o$-Xylene & Atmospheric & 3a & 40 \\
\hline 2 & 1a & 120 & 2 & $\mathrm{CH}_{2} \mathrm{Cl}_{2}$ & 10 & $3 \mathbf{a}$ & 51 \\
\hline 3 & $1 b$ & 180 & 4 & $o$-Xylene & Atmospheric & $3 \mathbf{b}$ & 46 \\
\hline 4 & $1 b$ & 120 & 2 & $\mathrm{CH}_{2} \mathrm{Cl}_{2}$ & 10 & $3 \mathbf{b}$ & 7 \\
\hline 5 & 1c & 180 & 3 & $o$-Xylene & Atmospheric & $3 c$ & 75 \\
\hline 6 & 1d & 180 & 3 & $o$-XYlene & Atmospheric & 3d & 17 \\
\hline 7 & $1 e$ & 180 & 3 & $o$-Xylene & Atmospheric & $3 e$ & 97 \\
\hline 8 & 1f & 160 & 3 & $o$-Xylene & Atmospheric & $3 f$ & 46 \\
\hline 9 & 1f & 180 & 3 & $o$-Xylene & Atmospheric & $5 a$ & 95 \\
\hline 10 & $1 \mathrm{~g}$ & 180 & 3 & Neat & Atmospheric & $3 g$ & 94 \\
\hline
\end{tabular}

with the aromatic system. The product $(\mathbf{1 0 b})$ was derived from the DA adduct (10c) by release of hydrogen and nitrogen dioxide $\left(\mathrm{HNO}_{2}\right)$.

Next, the stereochemistries of the ring juncture in $\mathbf{3 a}-\mathbf{f}$, $\mathbf{6 a}, \mathbf{b}, 7 \mathbf{a}, \mathbf{b}$, and $\mathbf{8 a}, \mathbf{b}$, were examined by the following way. The stereochemistries of the methoxycarbonyl, methoxy groups and $\mathrm{H}-10 \mathrm{a}$ in $7 \mathbf{a}$ were established by X-ray crystal structure determination (Fig. 1). This showed that the ring juncture in 7a was cis. The cis-stereochemistry of the ring juncture in 6a was determined by nuclear Overhauser effect (NOE) measurement of ${ }^{1} \mathrm{H}-\mathrm{NMR}$ spectra. Thus, when $\mathrm{H}-10 \mathrm{a}$ in 6a was irradiated, an NOE was observed between $\mathrm{H}-10 \mathrm{a}$ and methyl in the methoxycarbonyl group. It was determined that since both the demethanolations of 7a and 8a gave $\mathbf{6 a}$, that in $\mathbf{8 a}$ was also cis, that is, those in $6 \mathbf{a}, 7 \mathbf{a}$ and $\mathbf{8 a}$ were same. Similarly, the stereochemistries of those in $\mathbf{6 b}, \mathbf{7 b}$ and $\mathbf{8 b}$ were same. DA adducts were cis-forms according to the well-known Alder-Stein rule (cis-principle). In addition, in ${ }^{1} \mathrm{H}-\mathrm{NMR}$ spectra, the signals due to $\mathrm{H}-10 \mathrm{a}$ in $\mathbf{6 a}, 7 \mathbf{a}$, and $\mathbf{8 a}$ were located at 3.92, 3.97 and $3.47 \mathrm{ppm}$, and those of $\mathbf{6 b}, 7 \mathbf{b}$, and $8 \mathbf{b}$ appeared at $3.85,3.83$ and $3.74 \mathrm{ppm}$. Based on the above facts, the stereochemistries of the ring juncture in $\mathbf{6 b}$, $\mathbf{7 b}$, and $\mathbf{8 b}$ were deduced as cis. Moreover, the cis-stereochemistries of the ring juncture in $\mathbf{3 a}$ and $\mathbf{3 c}, \mathbf{d}$ was determined by NOE measurement. Thus, when H-10a was irradiated in the reduced form (4) of 3a mentioned above, an NOE was observed between $\mathrm{H}-10 \mathrm{a}$ and the methylene of the hydroxymethyl group. Similarly, the NOE of $\mathbf{3 c}, \mathbf{d}$ indicated the correlation between $\mathrm{H}-10 \mathrm{a}$ and the acetyl or formyl group. In ${ }^{1} \mathrm{H}-\mathrm{NMR}$ spectra, the signals due to $\mathrm{H}-10 \mathrm{a}$ in $\mathbf{3 a}, \mathbf{c}$, d were located at $3.45,3.68$ and $3.33 \mathrm{ppm}$ and those in $\mathbf{3 b}, \mathbf{e}, \mathbf{f}$ appeared at $3.33-3.99 \mathrm{ppm}$. From the these data, the stereochemistries of the ring juncture in $\mathbf{3 b}, \mathbf{e}, \mathbf{f}$ were deduced as cis. The stereochemistries of between the methoxycarbonyl and methoxy groups in $7 \mathbf{a}, \mathbf{b}$ and $\mathbf{8 a}, \mathbf{b}$ were examined in the following way. That in $7 \mathbf{a}$ was determined to be cis by X-ray crystal structure analysis as shown in Fig. 1. Since $\mathbf{7 a}, \mathbf{b}$ and $\mathbf{8 a}, \mathbf{b}$ were isomeric, that in $\mathbf{8 a}$ was confirmed to be trans. The demethanolation of $\mathbf{7 a}, \mathbf{b}$ proceeded faster than that of $\mathbf{8 a}, \mathbf{b}$ to reduce the steric hindrance between the methoxycar- 


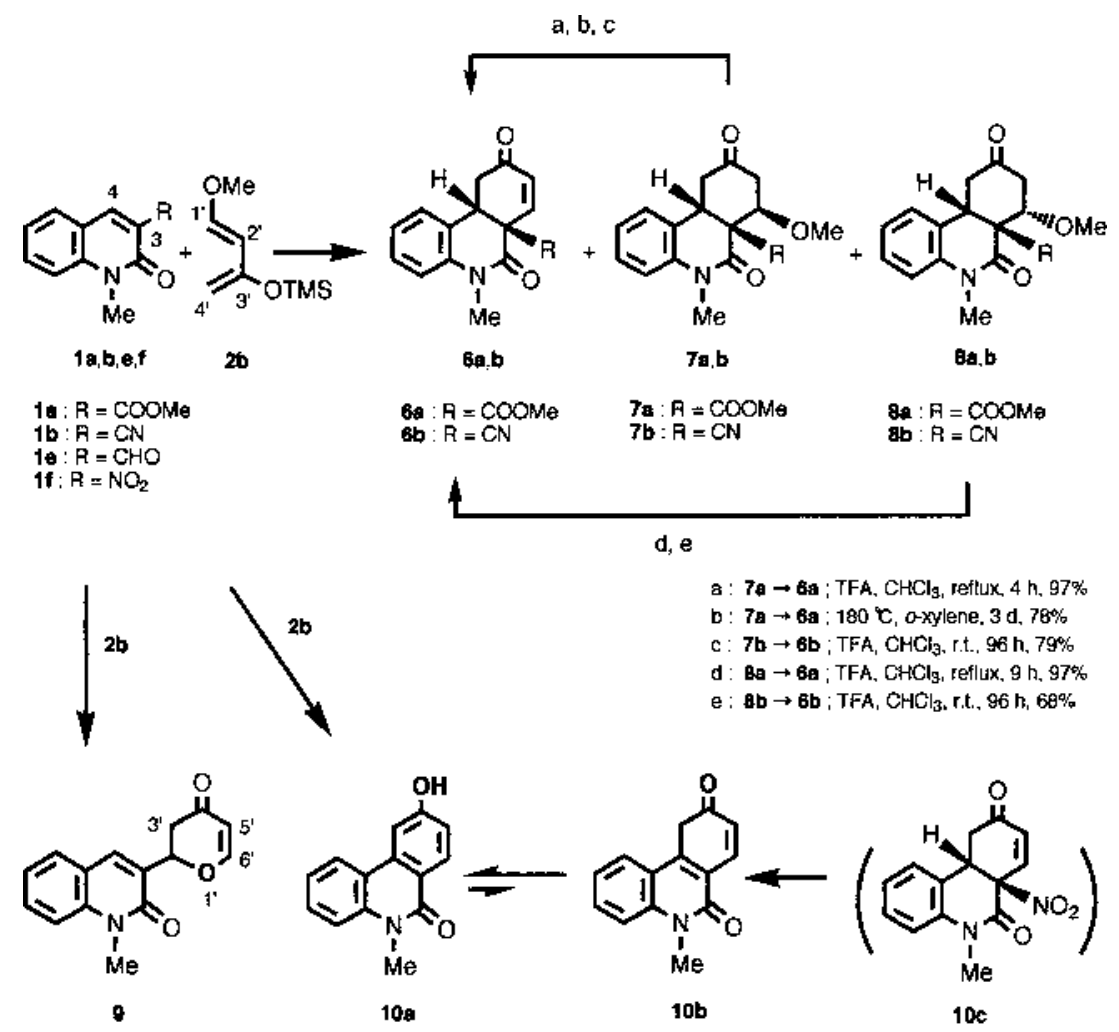

Chart 2

Table 2. DA Cycloadditions of $\mathbf{1 a}, \mathbf{b}, \mathbf{e}, \mathbf{f}$ with $\mathbf{2 b}$

\begin{tabular}{|c|c|c|c|c|c|c|c|c|}
\hline Entry & Substrate & Temp. $\left({ }^{\circ} \mathrm{C}\right)$ & Time (d) & Solvent & Pressure (kbar) & Work up $\left(\mathrm{CHCl}_{3}\right)$ & Adduct & Yield (\%) \\
\hline 1 & 1a & 180 & 4 & $o$-Xylene & Atmospheric & TFA-r.t. & $6 a$ & 93 \\
\hline 2 & $1 \mathrm{a}$ & 180 & 4 & $o$-Xylene & Atmospheric & $\mathrm{H}_{2} \mathrm{O}-$ r.t. & $7 a$ & 91 \\
\hline \multirow[t]{2}{*}{3} & 1a & 90 & 2 & $\mathrm{CH}_{2} \mathrm{Cl}_{2}$ & 10 & TFA-r.t. & $6 a$ & 62 \\
\hline & & & & & & & $8 a$ & 24 \\
\hline \multirow[t]{3}{*}{4} & 1a & 90 & 2 & $\mathrm{CH}_{2} \mathrm{Cl}_{2}$ & 10 & $\mathrm{H}_{2} \mathrm{O}-$ r.t. & $6 a$ & 32 \\
\hline & & & & & & & $7 a$ & Trace \\
\hline & & & & & & & $8 a$ & 40 \\
\hline 5 & $1 \mathrm{~b}$ & 180 & 3 & $o$-Xylene & Atmospheric & TFA-reflux & $\mathbf{6 b}$ & 98 \\
\hline \multirow[t]{3}{*}{6} & 1b & 180 & 3 & $o$-Xylene & Atmospheric & TFA-r.t. & $6 b$ & 66 \\
\hline & & & & & & & $7 b$ & 9 \\
\hline & & & & & & & $8 b$ & 9 \\
\hline \multirow[t]{3}{*}{7} & 1b & 90 & 2 & $\mathrm{CH}_{2} \mathrm{Cl}_{2}$ & 10 & TFA-r.t. & $6 b$ & 4 \\
\hline & & & & & & & $7 b$ & 9 \\
\hline & & & & & & & $8 b$ & 66 \\
\hline 8 & $1 \mathrm{e}$ & 160 & 2 & $o$-Xylene & Atmospheric & TFA-r.t. & 9 & 71 \\
\hline 9 & 1f & 180 & 3 & $o$-Xylene & Atmospheric & TFA-r.t. & $10 \mathrm{a}$ & 40 \\
\hline
\end{tabular}

bonyl and methoxy groups. Based on the above facts, it was deduced that the stereochemistry of $\mathbf{7 b}$ was cis and that of $\mathbf{8 b}$ was trans.

Regio-, Chemo-, and Stereoselectivity Since the diene and the dienophiles are unsymmetric in the DA reactions of $\mathbf{1 a}, \mathbf{b}$, and $\mathbf{1 f}$ with $\mathbf{2 b}$, regioisomers would be produced. In the present experiments, only the products from the $\left(1^{\prime}-3,4^{\prime}\right.$ 4 )-addition reactions were obtained. (The numbers of atoms are indicated in Chart 2.) But in the DA reaction of 4-substituted $2(1 H)$-quinolones with $\mathbf{2} \mathbf{b}$, only the adducts from $\left(1^{\prime}\right.$ $\left.4,4^{\prime}-3\right)$-addition reactions were produced. ${ }^{4)}$ We studied this regioselectivity theoretically using the stabilization energy $(\Delta E)$ expressed by Eq. 1 in ref. 4 as a reaction index. We optimized $\mathbf{1 a}, \mathbf{b}, \mathbf{f}, \mathbf{1} \mathbf{a}^{\prime}$, and $\mathbf{2} \mathbf{b}$ using the semi-empirical molec- ular orbital PM3 method. ${ }^{11)}$ Then we calculated $\Delta E$ considering only HOMO of the diene and LUMO of the dienophile. Table 3 summarizes the calculated values of $\Delta E$ together with the experimentally obtained products. As is seen from Table 3 , the calculated values of $\Delta E$ are consistent with the experimentally obtained products.

It is very interesting that the DA reaction of $1 \mathbf{e}$ with $\mathbf{2 a}$ produced the phenanthridone (3e) but did not form the adduct bearing a pyran ring. Whereas, the DA reaction of $1 \mathrm{e}$ with $\mathbf{2 b}$ gave $\mathbf{9}$ having a pyran ring but did not afford the phenanthridone. To study these differences theoretically, we searched and optimized the structures of transition states (TS) of the reactions using Gaussian 98 at RHF/6-31++ $\mathrm{G}(d, p) / / \mathrm{RHF} / 6-31 \mathrm{G}(d)$ level. ${ }^{13)}$ We assumed that the diene 
and dienophile were far apart in the initial state. We regarded the difference in energy between TS and the initial state as the activation energy $(E a)$. In Table 4, we summarize the calculated activation energies of these four reactions together with the experimental yields of adducts $(\mathbf{3 e}, \mathbf{9})$. We can see that $E a$ of the 3,4-addition for the reaction with $\mathbf{2 a}$ is smaller than that of the $\mathrm{HC}=\mathrm{O}$ addition. On the other hand, $E a$ of the

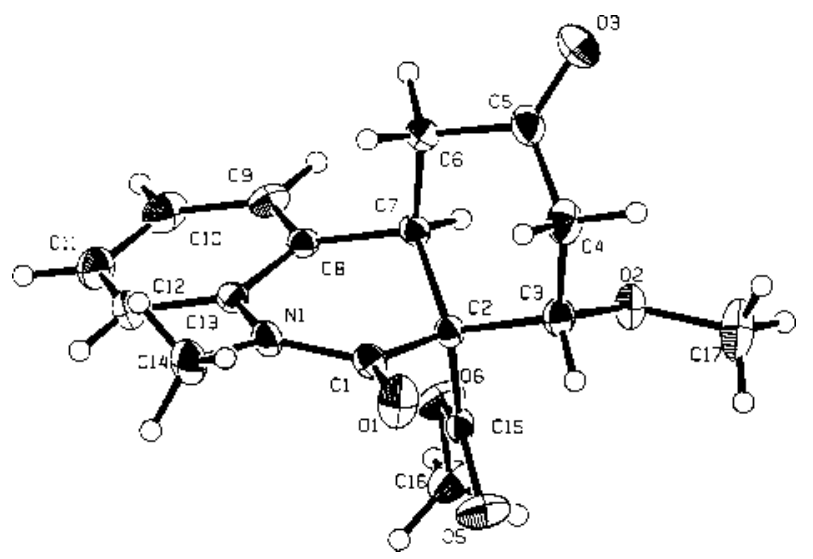

Fig. 1. ORTEP Drawing of $\mathbf{7 a}$

Table 3. Regioselectivity Based on the Stabilization Energy $(\Delta E)$ Caluclated Using PM3 Method

\begin{tabular}{|c|c|c|c|c|c|}
\hline \multirow{2}{*}{ Substrate } & \multirow{2}{*}{ Diene } & \multicolumn{2}{|c|}{$\left(1^{\prime}-3,4^{\prime}-4\right)$ Addition $\left.{ }^{a}\right)$} & \multicolumn{2}{|c|}{$\left(1^{\prime}-4,4^{\prime}-3\right)$ Addition $\left.^{a}\right)$} \\
\hline & & $\Delta E / \gamma^{2}$ & Adduct & $\Delta E / \gamma^{2}$ & Adduct \\
\hline $1 \mathrm{a}$ & $2 b$ & 0.0865 & $6 a, 7 a, 8 a$ & 0.0819 & - \\
\hline $1 b$ & $2 b$ & 0.0925 & $6 b, 7 b, 8 b$ & 0.0868 & - \\
\hline 1f & $2 b$ & 0.0964 & $10 a$ & 0.0873 & - \\
\hline $1 \mathbf{a}^{(b)}$ & $2 b$ & 0.0623 & - & 0.0647 & $7 \mathbf{a}^{\prime c)}$ \\
\hline
\end{tabular}

a) The numbers of atoms are indicated in Chart 2. b) 1a': 4-methoxycarbonyl$2(1 H)$-qunolone. ${ }^{4)}$ c) $\mathbf{7} \mathbf{a}^{\prime}$ : adduct from $\mathbf{1} \mathbf{a}^{\prime}{ }^{4)}$

Table 4. Experimental Yields of Adducts and Calculated Activation Energies for DA Cycloadditions of 1e with 2a, b

\begin{tabular}{|c|c|c|c|c|}
\hline \multirow{3}{*}{ Diene } & \multicolumn{4}{|c|}{$1 e$} \\
\hline & \multicolumn{2}{|c|}{ 3,4-Addition } & \multicolumn{2}{|c|}{$\mathrm{HC}=\mathrm{O}$ addition } \\
\hline & $\begin{array}{c}\left.E a^{a}\right) \\
(\mathrm{kcal} / \mathrm{mol})\end{array}$ & $\begin{array}{c}\text { Adduct } \\
\text { (yield \%) }\end{array}$ & $\begin{array}{c}E a^{a)} \\
(\mathrm{kcal} / \mathrm{mol})\end{array}$ & $\begin{array}{l}\text { Adduct } \\
\text { (yield \%) }\end{array}$ \\
\hline $2 \mathbf{a}$ & 43.04 & 97 & 48.98 & - \\
\hline $2 b$ & 32.34 & - & 31.37 & 71 \\
\hline
\end{tabular}

a) Calculated activation energy in unit of $\mathrm{kcal} / \mathrm{mol}$.
$\mathrm{HC}=\mathrm{O}$ addition for the reaction with $\mathbf{2} \mathbf{b}$ is smaller than that of the 3,4-addition. These results are consistent with the experimental yields of the adducts $(\mathbf{3 e}, \mathbf{9})$.

In the DA reactions of $\mathbf{1 a}$ and $\mathbf{1 b}$ with $\mathbf{2} \mathbf{b}$, the different stereoisomers were produced according to the reaction pressures (Table 2). To study this stereoselectivity, we searched and optimized the structures of TS and calculated the energies of the initial states and TS using Gaussian 98 at RHF/6$31 \mathrm{G}(d)$ level. ${ }^{12)}$ We display the structures of TS in the DA reactions of $1 \mathbf{a}$ with $\mathbf{2 b}$ in Fig. 2: TS(A) which would produce 7a (left) and TS(B) which would produce 8a (right). Table 5 summarizes the calculated values of the activation energies $(E a)$ and the corresponding adducts. The values of $E a$ are consistent with the adducts produced under AP (1 bar). However, the volume of TS will affect the rate of DA reaction under HP (10 kbar). We calculated the volumes of the molecules as the region within the $0.001 \mathrm{e} / \mathrm{bohr}^{3}$ density envelope $(1 \mathrm{bohr}=0.529 \AA)$. The calculate activation volume $(\mathrm{Va})$ of TS(A) has $-20.2 \mathrm{~A}^{3}$ and that of TS(B) has $-38.1 \mathrm{~A}^{3}$. The value of $p V a$ at $p=10 \mathrm{kbar}$ for TS(A) is $-2.93 \mathrm{kcal} / \mathrm{mol}$ and that for TS(B) becomes $-14.67 \mathrm{kcal} / \mathrm{mol}$. The values of $p V a$ at $p=1$ bar are practically zero. Then we can obtain the activation enthalpy $(\mathrm{Ha})$ of the reaction by the following formula:

\section{$H a=E a+p V a$}

The calculated values of $H a$ are also listed in Table 5. The values of $\mathrm{Ha}$ are consistent with the experimental adducts under HP. Thus we can explain the adducts obtained under both AP and HP conditions in terms of the values of $\mathrm{Ha}$. As

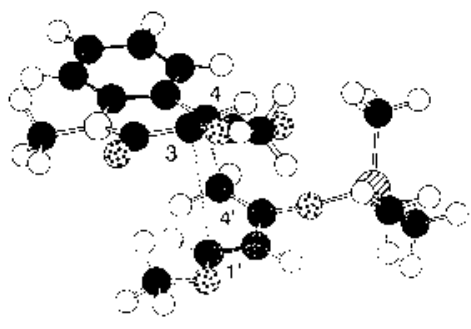

$\operatorname{TS}(\mathrm{A})$

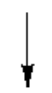

$7 a$

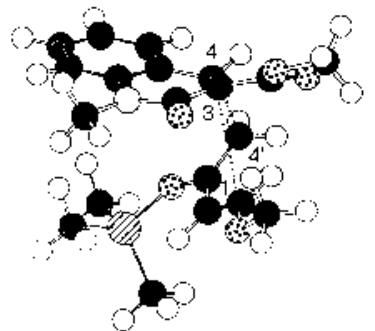

TS(B)

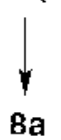

Fig. 2. Calculated Structures of TS in the DA Reactions of 1a with $\mathbf{2 b}$ : TS(A) Which Would Produce 7a (Left) and TS(B) Which Would Produce 8a (Right)

The calculated relevant interatomic distances are: $\mathrm{C}_{1}, \mathrm{C}_{3}=3.181 \AA, \mathrm{C}_{4}, \mathrm{C}_{4}=1.993 \AA$ (left); $\mathrm{C}_{1} \mathrm{C}_{3}=3.097 \AA, \mathrm{C}_{4^{\prime}} \mathrm{C}_{4}=1.960 \AA$ (right).

Table 5. Stereoselectivity in the DA Reaction of $\mathbf{1 a}$ and $\mathbf{1 b}$ with $\mathbf{2 b}$. Activation Energies $(E a)$ and Enthalpies $(H a)$ Were Calculated Using RHF/6-31G (d) Basis Set

\begin{tabular}{|c|c|c|c|c|c|c|c|c|}
\hline \multirow{2}{*}{ Dienophile } & \multirow{2}{*}{ Diene } & \multirow{2}{*}{ Pressure } & \multicolumn{3}{|c|}{ via $\mathrm{TS}(\mathrm{A})$} & \multicolumn{3}{|c|}{ via $\mathrm{TS}(\mathrm{B})$} \\
\hline & & & $\begin{array}{c}E a \\
(\mathrm{kcal} / \mathrm{mol})\end{array}$ & $\begin{array}{c}H a \\
(\mathrm{kcal} / \mathrm{mol})\end{array}$ & $\begin{array}{c}\text { Adduct } \\
\text { (yield \%) }\end{array}$ & $\begin{array}{c}E A \\
(\mathrm{kcal} / \mathrm{mol})\end{array}$ & $\begin{array}{c}H a \\
(\mathrm{kcal} / \mathrm{mol})\end{array}$ & $\begin{array}{c}\text { Adduct } \\
\text { (yield \%) }\end{array}$ \\
\hline \multirow[t]{2}{*}{$1 \mathrm{a}$} & $2 b$ & $1 \mathrm{~atm}$ & 29.54 & 29.54 & $7 \mathbf{a}(91 \%)$ & 31.26 & 31.26 & - \\
\hline & & $10 \mathrm{kbar}$ & 29.54 & 26.61 & - & 31.26 & 25.78 & 8a $(24 \%)$ \\
\hline \multirow[t]{2}{*}{$1 b$} & $2 b$ & $1 \mathrm{~atm}$ & 32.91 & 32.91 & $7 \mathbf{b}(12 \%)$ & 33.62 & 33.62 & $8 \mathbf{b}(6 \%)$ \\
\hline & & $10 \mathrm{kbar}$ & 32.91 & 30.19 & $7 \mathbf{b}(9 \%)$ & 33.62 & 28.52 & $\mathbf{8 b}(66 \%)$ \\
\hline
\end{tabular}


is seen from Table 2, the yields of adducts under HP are comparable with those under AP, although the reactions under HP were performed at the lower temperature and the shorter reaction time. We can understand this fact by considering that the DA reactions were accelerated under HP because of the negative values of $\mathrm{Va}$ and consequently the smaller values of $\mathrm{Ha}$.

In conclusion, thermal DA cycloadditions of 3-substituted $2(1 H)$-quinolones having an electron-withdrawing group (such as $\mathrm{COOMe}, \mathrm{CN}, \mathrm{COMe}, \mathrm{COPh}, \mathrm{NO}_{2}$ ) with alkyl- and silyloxy-1,3-butadienes $(\mathbf{2 a}, \mathbf{b})$ produced phenanthridones richly functionalized regio- or stereoselectively under AP and HP conditions and the reactions of 3-nitro-2 $(1 H)$-quinolones with 2a, b gave aromatized phenanthridones. Moreover, regioselectivity of 3 -substituted $2(1 H)$-quinolones to $\mathbf{2 b}$ was examined by stabilization energy $(\Delta E)$ using semi-empirical MO calculation. Further, DA reactions of 3-formyl-2(1H)quinolone with $\mathbf{2 a}, \mathbf{b}$ afforded chemoselectively a phenanthridone or the hetero DA adduct in fairly good yield and these results were supported by the activation energy (Ea) using $a b$ initio MO calculation.

\section{Experimental}

The following instruments were used to obtain physical data: Melting points, Yanaco micro-melting point apparatus (values are uncorrected); IR spectra, Perkin Elmer ET-IR 1725X spectrometer; MS, JEOLJMS-DX 303/JMA-DA5000 spectrometer; NMR spectra, JNM-XX $600 \mathrm{MHz}$, JNMGSX400 ( $\left.{ }^{1} \mathrm{H}-\mathrm{NMR} ; 400 \mathrm{MHz},{ }^{13} \mathrm{C}-\mathrm{NMR} ; 100 \mathrm{MHz}\right)$, JNM-EX270 $\left({ }^{1} \mathrm{H}-\right.$ NMR; $270 \mathrm{MHz},{ }^{13} \mathrm{C}-\mathrm{NMR} ; 67.5 \mathrm{MHz}$ ), JEOLJNM-PMX $60_{\text {SI }}$ spectrometer with tetramethylsilane (TMS) as an internal standard; elemental analyses, Perkin Elmer 2400 CHN Elemental Analyzer. The following experimental conditions were used for chromatography; column chromatography, Merk Kieselgel Silica-gel 60 (230 - 400 mesh); TLC, pre-coated TLC plates with $60 \mathrm{~F}_{254}(2 \mathrm{~mm}$, Merck).

Synthesis of 3-Acetyl-1-methyl-2(1H)-quinolone (1c) After a solution of 3-methoxycarbonyl-1-methyl-2(1H)-quinolone (1a, $2.17 \mathrm{~g}, 10 \mathrm{mmol})$ and sodium methoxide ( $801 \mathrm{mg}, 15 \mathrm{mmol})$ in $20 \mathrm{ml}$ ethyl acetate was stirred for $7 \mathrm{~h}$ while refluxing in an oil bath, conc- $\mathrm{HCl}(30 \mathrm{ml})$ and water $(60 \mathrm{ml})$ were added. The acidic solution was refluxed for $3 \mathrm{~h}$, basified with $\mathrm{K}_{2} \mathrm{CO}_{3}$ and extracted with chloroform. The chloroform extract was dried over $\mathrm{Na}_{2} \mathrm{SO}_{4}$, and evaporated to give 1c ( $2.0 \mathrm{~g}$, quantitative ).

1c: Pale yellow plates (acetone), mp $110-114^{\circ} \mathrm{C}$. IR $(\mathrm{KBr}) \mathrm{cm}^{-1}$ : 1678, 1653, 1611. ${ }^{1} \mathrm{H}-\mathrm{NMR}\left(\mathrm{CDCl}_{3}\right) \delta: 2.77(3 \mathrm{H}, \mathrm{s}, \mathrm{COMe}), 3.76(3 \mathrm{H}, \mathrm{s}, \mathrm{Me}-\mathrm{N})$, $7.28(1 \mathrm{H}$, ddd, $J=1.0,7.8,7.8 \mathrm{~Hz}, \mathrm{H}-6$ or 7$), 7.38(1 \mathrm{H}, \mathrm{d}, J=8.1 \mathrm{~Hz}, \mathrm{H}-5$ or 8), $7.64-7.72(2 \mathrm{H}, \mathrm{m}, \mathrm{H}-5$ or 8,6 or 7$), 8.40(1 \mathrm{H}, \mathrm{s}, \mathrm{H}-4) .{ }^{13} \mathrm{C}-\mathrm{NMR}$ $\left(\mathrm{CDCl}_{3}\right) \delta: 29.60,31.00,114.03,119.14,122.46,128.89,130.98,132.88$, 141.34, 142.32, 160.47, 197.99. MS m/z: $201\left(\mathrm{M}^{+}\right), 186$. HR-MS $m / z$ : Calcd for $\mathrm{C}_{12} \mathrm{H}_{11} \mathrm{NO}_{2}$, 201.0790. Found: 201.0789.

Synthesis of 3-Benzoyl-1-methyl-2(1H)-quinolone (1d) A suspension of 1-methyl-2(1H)-quinolone-3-carboxylic acid $(2.03 \mathrm{~g}, 10 \mathrm{mmol})$ hydrolyzed 1a and thionyl chloride $(3.57 \mathrm{~g}, 30 \mathrm{mmol})$ was refluxed for $3 \mathrm{~h}$, and evaporated in vacuo. The solution of the residue in $30 \mathrm{ml}$ benzene and $\mathrm{AlCl}_{3}$ $(2.67 \mathrm{~g}, 20 \mathrm{mmol})$ was refluxed for $6 \mathrm{~h}$, and made basic with $10 \% \mathrm{NaOH}$. The benzene layer was dried over $\mathrm{Na}_{2} \mathrm{SO}_{4}$ and evaporated in vacuo. The residue was chromatographed on a column of alumina. The solvent of the fraction eluted with acetone-hexane $(1: 3)$ was evaporated to give $\mathbf{1 d}(2.0 \mathrm{~g}$, $76 \%)^{8)}$

General Procedure for DA Cycloadditions of 1a, 3-Cyano-1-methyl2(1H)-quinolone (1b), 1c, 1d, 3-Formyl-1-methyl-2(1H)-quinolone (1e), 1-Methyl-3-nitro-2(1H)-quinolone (1f), 1-Methyl-3,6-dinitro-2(1H)quinolone (1g) with $2 \mathrm{a}$ The solution of $\mathbf{1 a}(217 \mathrm{mg}, 1 \mathrm{mmol})$ and $\mathbf{2 a}$ $(410 \mathrm{mg}, 5 \mathrm{mmol})$ in $o$-xylene $(3 \mathrm{ml})$ was heated at $180^{\circ} \mathrm{C}$ for $3 \mathrm{~d}$ in a sealed tube and the reaction mixture was concentrated in vacuo. The residue was chromatographed on a column of silica-gel. The solvent of the fraction eluted with acetone-hexane $(1: 2)$ was evaporated. The crude product was purified by preparative TLC over silica-gel with acetone-hexane $(1: 3)$ to give cis-5,6,6a,7,10,10a-hexahydro-6a-methoxycarbonyl-5,8,9-trimethylphenanthridin-6-one (3a). The reactions of $\mathbf{1 b}-\mathbf{g}(1 \mathrm{mmol})$ with $\mathbf{2 a}$ $(5 \mathrm{mmol})$ were carried out under the conditions listed in Table 1 and the crude products were purified using the same procedure as described above to give cis-6a-cyano-5,6,6a,7,10,10a-hexahydro-5,8,9-trimethylphenanthridin6-one (3b), cis-6a-acetyl-5,6,6a,7,10,10a-hexahydro-5,8,9-trimethylphenanthridin-6-one (3c), cis-6a-benzoyl-5,6,6a, 7, 10,10a-hexahydro-5,8,9trimethylphenanthridin-6-one (3d), cis-6a-formyl-5,6,6a,7,10,10a-hexahydro-5,8,9-trimethylphenanthridin-6-one (3e), cis-5,6,6a,7,10,10a-hexahydro6a-nitro-5,8,9-trimethylphenanthridin-6-one (3f), cis-5,6,6a,7,10,10a-hexahydro-2,6a-dinitro-5,8,9-trimethylphenanthridin-6-one (3g), 5,8,9-trimethylphenanthridin-6-one (5a), respectively. The yields of $\mathbf{3 a -} \mathbf{g}$ and $\mathbf{5 a}$ are summarized in Table 1.

3a: Colorless columns (acetone-hexane), mp $139-141^{\circ} \mathrm{C}$. IR (KBr) $\mathrm{cm}^{-1}: 1729,1678,1605 .{ }^{1} \mathrm{H}-\mathrm{NMR}\left(\mathrm{CDCl}_{3}\right) \delta: 1.59(3 \mathrm{H}, \mathrm{s}, \mathrm{Me}-\mathrm{C}), 1.68$ $(3 \mathrm{H}, \mathrm{s}, \mathrm{Me}-\mathrm{C}), 1.99$ (1H, dd, $J=18.2,10.9 \mathrm{~Hz}, \mathrm{H}-10), 2.15(1 \mathrm{H}, \mathrm{dd}, J=18.2$, $6.6 \mathrm{~Hz}, \mathrm{H}-10), 2.38(1 \mathrm{H}, \mathrm{d}, J=17.0 \mathrm{~Hz}, \mathrm{H}-7), 2.93(1 \mathrm{H}, \mathrm{d}, J=17.0 \mathrm{~Hz}, \mathrm{H}-7)$, $3.41(3 \mathrm{H}, \mathrm{s}, \mathrm{Me}-\mathrm{N}), 3.45(1 \mathrm{H}, \mathrm{dd}, J=6.6,10.9 \mathrm{~Hz}, \mathrm{H}-10 \mathrm{a}), 3.51(3 \mathrm{H}, \mathrm{s}$, COOMe), 6.97-7.04 (2H, m, H-aromatic), 7.16-7.28 (2H, m, H-aromatic). ${ }^{13} \mathrm{C}-\mathrm{NMR}\left(\mathrm{CDCl}_{3}\right) \delta: 18.6,18.7,30.3,34.7,35.2,38.4,52.6,53.6$, $115.0,122.9,123.3,123.6,127.3,127.7,129.2,138.6,167.9,172.7 . \mathrm{MS}$ $m / z: 299\left(\mathrm{M}^{+}\right), 240,217$. Anal. Calcd for $\mathrm{C}_{18} \mathrm{H}_{21} \mathrm{NO}_{3}: \mathrm{C}, 72.21 ; \mathrm{H}, 7.07 ; \mathrm{N}$, 4.68. Found: C, 73.32; H, 7.12; N, 4.55.

3b: Colorless columns (acetone-hexane), mp 172-173 ${ }^{\circ} \mathrm{C}$. IR $(\mathrm{KBr})$ $\mathrm{cm}^{-1}: 2233,1681,1607 .{ }^{1} \mathrm{H}-\mathrm{NMR}\left(\mathrm{CDCl}_{3}\right) \delta: 1.62(3 \mathrm{H}, \mathrm{s}, \mathrm{Me}-\mathrm{C}), 1.67$ $(3 \mathrm{H}, \mathrm{s}, \mathrm{Me}-\mathrm{C}), 2.14(1 \mathrm{H}, \mathrm{dd}, J=9.3,17.5 \mathrm{~Hz}, \mathrm{H}-10), 2.30(1 \mathrm{H}, \mathrm{dd}, J=5.3$, $17.5 \mathrm{~Hz}, \mathrm{H}-10), 2.49$ (1H, d, $J=17.2 \mathrm{~Hz}, \mathrm{H}-7), 2.97(1 \mathrm{H}, \mathrm{d}, J=17.2 \mathrm{~Hz}, \mathrm{H}-7$ ), $3.43(3 \mathrm{H}, \mathrm{s}, \mathrm{Me}-\mathrm{N}), 3.33(1 \mathrm{H}, \mathrm{dd}, J=5.3,9.3 \mathrm{~Hz}, \mathrm{H}-10 \mathrm{a}), 7.06-7.38(4 \mathrm{H}$, $\mathrm{m}, \mathrm{H}$-aromatic). ${ }^{13} \mathrm{C}-\mathrm{NMR}\left(\mathrm{CDCl}_{3}\right) \delta: 18.4,18.8,30.9,33.6,35.0,39.1$, 42.3, 115.6, 119.4, 122.4, 123.3, 124.1, 127.0, 127.3, 128.6, 138.3, 163.4 . MS $m / z: 266\left(\mathrm{M}^{+}\right)$, 184. Anal. Calcd for $\mathrm{C}_{17} \mathrm{H}_{18} \mathrm{~N}_{2} \mathrm{O}: \mathrm{C}, 76.66 ; \mathrm{H}, 6.81 ; \mathrm{N}$, 10.51. Found: C, $76.88 ; \mathrm{H}, 6.81 ; \mathrm{N}, 10.48$.

3c: Colorless powder (ether), mp $130-131^{\circ} \mathrm{C}$. IR $(\mathrm{KBr}) \mathrm{cm}^{-1}$ : 1709 , 1669, 1604. ${ }^{1} \mathrm{H}-\mathrm{NMR}\left(\mathrm{CDCl}_{3}\right) \delta: 1.59(3 \mathrm{H}, \mathrm{s}, \mathrm{Me}-\mathrm{C}), 1.69(3 \mathrm{H}, \mathrm{s}, \mathrm{Me}-\mathrm{C})$, 1.93-2.27 (3H, m, H-7, 10, 10), $2.04(3 \mathrm{H}, \mathrm{s}, \mathrm{COMe}), 2.95(1 \mathrm{H}, \mathrm{d}$, $J=17.0 \mathrm{~Hz}, \mathrm{H}-7), 3.39-3.68(1 \mathrm{H}, \mathrm{m}, \mathrm{H}-10 \mathrm{a}), 3.42(3 \mathrm{H}, \mathrm{s}, \mathrm{Me}-\mathrm{N}), 6.95-$ 7.05 (2H, m, H-aromatic), 7.18-7.26 (2H, m, H-aromatic). ${ }^{13} \mathrm{C}-\mathrm{NMR}$ $\left(\mathrm{CDCl}_{3}\right) \delta: 18.6,18.72,26.2,30.2,34.8,35.2,37.3,59.6,115.1123 .4(\mathrm{C} 2)$, 123.5, 127.5, 127.7, 129.9 (C2), 138.3, 169.1, 205.8. MS m/z: $283\left(\mathrm{M}^{+}\right)$, 240, 224, 198. HR-MS $m / z$ : Calcd for $\mathrm{C}_{18} \mathrm{H}_{21} \mathrm{NO}_{2}\left(\mathrm{M}^{+}\right)$: 283.1572 . Found: 283.1608. Anal. Calcd for $\mathrm{C}_{18} \mathrm{H}_{21} \mathrm{NO}_{2}$ : C, 76.29; H, 7.47; N, 4.94. Found: $\mathrm{C}$, 76.65; H, 7.76; N, 4.89 .

3d: Colorless needles (ether-hexane), mp $127-1219^{\circ} \mathrm{C}$. IR $(\mathrm{KBr}) \mathrm{cm}^{-1}$ : $1681,1665,1604,1416,697 .{ }^{1} \mathrm{H}-\mathrm{NMR}\left(\mathrm{CDCl}_{3}\right) \delta: 1.63(3 \mathrm{H}, \mathrm{s}, \mathrm{Me}-\mathrm{C}), 1.71$ $(3 \mathrm{H}, \mathrm{s}, \mathrm{Me}-\mathrm{C}), 2.06-2.20(2 \mathrm{H}, \mathrm{br} \mathrm{m}, J=6.4,17.6 \mathrm{~Hz}, \mathrm{H}-10,102.44(1 \mathrm{H}, \mathrm{d}$, $J=17.0 \mathrm{~Hz}, \mathrm{H}-7), 3.10(1 \mathrm{H}, \mathrm{d}, J=17.0 \mathrm{~Hz}, \mathrm{H}-7), 3.25(3 \mathrm{H}, \mathrm{s} \mathrm{Me}-\mathrm{N}), 3.67$ $(1 \mathrm{H}, \mathrm{dd}, J=6.4,10.4 \mathrm{~Hz}, \mathrm{H}-10 \mathrm{a}), 6.77(1 \mathrm{H}, \mathrm{dd}, J=1.1,8.1 \mathrm{~Hz}, \mathrm{H}-4), 7.00$ (1H, ddd, $J=1.0,7.9,7.9 \mathrm{~Hz}, \mathrm{H}-2), 7.14-7.19$ (2H, br m, H-1, 3), 7.26$7.32\left(2 \mathrm{H}, \mathrm{brm}, \mathrm{H}-3^{\prime}, 5^{\prime}\right), 7.43\left(1 \mathrm{H}, \mathrm{dd}, J=1.5,8.5 \mathrm{~Hz}, \mathrm{H}-4^{\prime}\right), 7.57-7.60$ $\left(2 \mathrm{H}\right.$, br m, $\left.J=1.5,8.5 \mathrm{~Hz}, \mathrm{H}_{-}{ }^{\prime}, 6^{\prime}\right) .{ }^{13} \mathrm{C}-\mathrm{NMR}\left(\mathrm{CDCl}_{3}\right) \delta: 18.7,18.9,20.4$, $34.5,36.0,39.0,58.7,115.0,122.8,123.4,123.9,127.4,127.5,127.9$ (C2), 128.0 (C2), 130.0, 131.9, 137.5, 138.6, 169.5, 200.5. MS m/z: $345\left(\mathrm{M}^{+}\right)$, 240,172. HR-MS $m / z$ : Calcd for $\mathrm{C}_{23} \mathrm{H}_{23} \mathrm{NO}_{2}\left(\mathrm{M}^{+}\right)$: 345.1729. Found: 345.1722 .

3e: Colorless needles (ether-hexane), $\mathrm{mp} 114^{\circ} \mathrm{C}$. IR $(\mathrm{KBr}) \mathrm{cm}^{-1}$ : 1731 , 1674, 1605. ${ }^{1} \mathrm{H}-\mathrm{NMR}\left(\mathrm{CDCl}_{3}\right) \delta$ : $1.61(3 \mathrm{H}, \mathrm{s}, \mathrm{Me}-\mathrm{C}), 1.70(3 \mathrm{H}, \mathrm{s}, \mathrm{Me}-\mathrm{C})$, 2.04-2.16 (2H, m, H-10, 10), $2.21(1 \mathrm{H}, \mathrm{d}, J=17.0 \mathrm{~Hz}, \mathrm{H}-7), 2.75(1 \mathrm{H}, \mathrm{d}$, $J=17.0 \mathrm{~Hz}, \mathrm{H}-7), 3.33(1 \mathrm{H}, \mathrm{dd}, J=6.5,10.0 \mathrm{~Hz}, \mathrm{H}-10 \mathrm{a}), 3.42(3 \mathrm{H}, \mathrm{s}$, Me-N), 6.98-7.07 (2H, m, 2, H-4), $7.18(1 \mathrm{H}, \mathrm{dd}, J=1.4,7.5 \mathrm{~Hz}, \mathrm{H}-1)$, $7.24-7.30(1 \mathrm{H}, \mathrm{dd}, J=1.8,7.1 \mathrm{~Hz}, \mathrm{H}-3), 9.37(1 \mathrm{H}, \mathrm{s}, \mathrm{CHO}) .{ }^{13} \mathrm{C}-\mathrm{NMR}$ $\left(\mathrm{CDCl}_{3}\right) \delta: 18.6,18.8,30.2,30.9,34.4,36.0,57.7,115.2,122.8,123.5$, 123.5, 127.2, 127.8, 128.2, 138.7, 167.7, 198.3. MS $m / z: 269\left(\mathrm{M}^{+}\right), 251$, 240, 198. HR-MS $\mathrm{m} / \mathrm{z}$ : Calcd for $\mathrm{C}_{17} \mathrm{H}_{19} \mathrm{NO}_{2}\left(\mathrm{M}^{+}\right)$: 269.1416. Found: 269.1407.

3f: Colorless powder (ether-acetone ), $\mathrm{mp} 162-165^{\circ} \mathrm{C}$. IR $(\mathrm{KBr}) \mathrm{cm}^{-1}$ : $1650,1606,1546,1381 .{ }^{1} \mathrm{H}-\mathrm{NMR}\left(\mathrm{CDCl}_{3}\right) \delta: 1.61(3 \mathrm{H}, \mathrm{s}, \mathrm{Me}-\mathrm{C}), 1.71(3 \mathrm{H}$, s, Me-C), $2.06(1 \mathrm{H}, \mathrm{dd}, J=10.5,18.1 \mathrm{~Hz}, \mathrm{H}-10), 2.38(1 \mathrm{H}, \mathrm{dd}, J=6.7$, $18.1 \mathrm{~Hz}, \mathrm{H}-10), 2.75(1 \mathrm{H}, \mathrm{d}, J=16.8 \mathrm{~Hz}, \mathrm{H}-7), 3.21(1 \mathrm{H}, \mathrm{d}, J=16.8 \mathrm{~Hz}, \mathrm{H}-7)$, $3.48(3 \mathrm{H}, \mathrm{s}, \mathrm{Me}-\mathrm{N}), 3.86(1 \mathrm{H}, \mathrm{dd}, J=6.7,10.5 \mathrm{~Hz}, \mathrm{H}-10 \mathrm{a}), 7.03-7.09(2 \mathrm{H}$, $\mathrm{m}, \mathrm{H}-1,3), 7.18(1 \mathrm{H}, \mathrm{dd}, J=1.7,7.5 \mathrm{~Hz}, \mathrm{H}-4), 7.26-7.33(1 \mathrm{H}, \mathrm{m}, \mathrm{H}-2)$. ${ }^{13} \mathrm{C}-\mathrm{NMR}\left(\mathrm{CDCl}_{3}\right) \delta: 18.4,18.5,30.6,35.7,36.4,40.1,91.1,115.5,122.8$, $123.1,124.0,126.2,127.7,128.6,137.8,161.9$. MS $m / z: 286,240$ $\left(\mathrm{M}^{+}-\mathrm{NO}_{2}\right), 224,172$. HR-MS $\mathrm{m} / \mathrm{z}$ : Calcd for $\mathrm{C}_{16} \mathrm{H}_{18} \mathrm{~N}_{2} \mathrm{O}_{3}: 286.1317$. Found: 286.1292 .

3g: Colorless needles (ether), $\mathrm{mp} 180^{\circ} \mathrm{C}$. IR $(\mathrm{KBr}) \mathrm{cm}^{-1}$ : 1549,1372 , $1522,1342,1615,1597 .{ }^{1} \mathrm{H}-\mathrm{NMR}\left(\mathrm{CDCl}_{3}\right) \delta: 1.63(3 \mathrm{H}, \mathrm{s}, \mathrm{Me}-\mathrm{C}), 1.73(3 \mathrm{H}$, $\mathrm{s}, \mathrm{Me}-\mathrm{C}), 2.07(1 \mathrm{H}, \mathrm{dd}, J=11.0,18.0 \mathrm{~Hz}, \mathrm{H}-10), 2.47(1 \mathrm{H}, \mathrm{dd}, J=7.0$, $18.0 \mathrm{~Hz}, \mathrm{H}-10), 2.80(1 \mathrm{H}, \mathrm{d}, J=17.0 \mathrm{~Hz}, \mathrm{H}-7), 3.54(3 \mathrm{H}, \mathrm{s}, \mathrm{Me}-\mathrm{N}), 3.99$ 
$(1 \mathrm{H}, \mathrm{dd}, J=7.0,11.0 \mathrm{~Hz}, \mathrm{H}-10 \mathrm{a}), 7.16(1 \mathrm{H}, \mathrm{d}, J=9.0 \mathrm{~Hz}, \mathrm{H}-4), 8.10(1 \mathrm{H}, \mathrm{d}$, $J=2.6 \mathrm{~Hz}, \mathrm{H}-1), 8.21(1 \mathrm{H}, J=2.6,9.0 \mathrm{~Hz}, \mathrm{H}-3) .{ }^{13} \mathrm{C}-\mathrm{NMR}\left(\mathrm{CDCl}_{3}\right) \delta: 18.4$, 18.5, 31.1, 35.3, 36.1, 40.0, 90.4, 115.7, 122.8, 122.9, 123.3, 124.6, 127.1, 143.1, 143.5, 161.9. MS m/z: $285\left(\mathrm{M}^{+}-\mathrm{NO}_{2}\right), 239,217$. HR-MS $m / z$ : Calcd for $\mathrm{C}_{16} \mathrm{H}_{17} \mathrm{~N}_{2} \mathrm{O}_{3}\left(\mathrm{M}^{+}-\mathrm{NO}_{2}\right)$ : 285.1239. Found: 285.1265 .

5a: Pale yellow needles (ether), $\mathrm{mp} 212-213^{\circ} \mathrm{C}$. IR $(\mathrm{KBr}) \mathrm{cm}^{-1}$ : 1651, 1619, 789, 739. ${ }^{1} \mathrm{H}-\mathrm{NMR}\left(\mathrm{CDCl}_{3}\right): 2.42(3 \mathrm{H}, \mathrm{s}, \mathrm{Me}-\mathrm{C}), 2.45(3 \mathrm{H}, \mathrm{s}, \mathrm{Me}-\mathrm{C})$, $3.79(3 \mathrm{H}, \mathrm{s}, \mathrm{Me}-\mathrm{N}), 7.25-7.49(2 \mathrm{H}, \mathrm{m}, \mathrm{H}$-aromatic $), 7.47-7.49(1 \mathrm{H}, \mathrm{m}$, $\mathrm{H}$-aromatic), $7.51(1 \mathrm{H}, \mathrm{dd}, J=1.5,7.9 \mathrm{~Hz}, \mathrm{H}$-aromatic), $7.99(1 \mathrm{H}, \mathrm{s}, \mathrm{H}-10)$, $8.22\left(1 \mathrm{H}, \mathrm{dd}, J=1.5,7.9 \mathrm{~Hz}, \mathrm{H}\right.$-aromatic), $8.27(1 \mathrm{H}, \mathrm{s}, \mathrm{H}-7) .{ }^{13} \mathrm{C}-\mathrm{NMR}$ $\left(\mathrm{CDCl}_{3}\right) \delta: 19.7,20.5,29.83,114.8,119.2,122.1(\mathrm{C} 2), 122.7,123.4,128.7$, 128.9, 131.2, 137.1, 137.7, 141.8, 161.5. MS m/z: $237\left(\mathrm{M}^{+}\right), 222,206,194$. HR-MS $m / z$ : Calcd for $\mathrm{C}_{16} \mathrm{H}_{15} \mathrm{NO}\left(\mathrm{M}^{+}\right): 237.1154$. Found: 237.1150 .

Heating of $3 \mathrm{~g}$ The solution of $3 \mathrm{~g}(33 \mathrm{mg}, 0.12 \mathrm{mmol})$ in $2 \mathrm{ml} o$-xylene was heated at $180^{\circ} \mathrm{C}$ for $2 \mathrm{~d}$ and then concentrated in vacuo. The residue was purified by preparative TLC over silica gel with hexane-acetone $(1: 3)$ to give 5,8,9-trimethyl-2-nitrophenanthridin-6-one [5b, $18 \mathrm{mg},(64 \%)]$.

5b: Pale yellow needles (acetone), $\mathrm{mp} 270^{\circ} \mathrm{C}$. IR $(\mathrm{KBr}) \mathrm{cm}^{-1}$ : 1661 , $1609,1519,1335 .{ }^{1} \mathrm{H}-\mathrm{NMR}\left(\mathrm{CDCl}_{3}\right) \delta: 2.55(3 \mathrm{H}, \mathrm{s}, \mathrm{C}-\mathrm{Me}), 2.62(3 \mathrm{H}, \mathrm{s}$, $\mathrm{Me}-\mathrm{C}), 4.08(3 \mathrm{H}, \mathrm{s}, \mathrm{Me}-\mathrm{N}), 7.83(1 \mathrm{H}, \mathrm{d}, J=9.5 \mathrm{~Hz}, \mathrm{H}-4), 8.29(1 \mathrm{H}, \mathrm{s}, \mathrm{H}-7$ or 10$), 8.32(1 \mathrm{H}, \mathrm{s}, \mathrm{H}-7$ or 10$), 8.52(1 \mathrm{H}, \mathrm{dd}, J=2.4,9.5 \mathrm{~Hz}, \mathrm{H}-3), 9.34(1 \mathrm{H}$, d, $J=2.4 \mathrm{~Hz}, \mathrm{H}-1) .{ }^{13} \mathrm{C}-\mathrm{NMR}\left(\mathrm{CDCl}_{3}\right) \delta: 20.4,21.2,33.1,119.2,123.2$, $123.7,124.8,125.3,125.9,130.7,133.2,142.9,125.3,130.7,133.2,142.9$, 143.2, 145.6, 148.7, 163.5. MS $m / z$ : $282\left(\mathrm{M}^{+}\right), 252,236$. HR-MS $m / z$ : Calcd for $\mathrm{C}_{16} \mathrm{H}_{14} \mathrm{~N}_{2} \mathrm{O}_{3}\left(\mathrm{M}^{+}\right): 282.1034$. Found: 282.1035 .

Reduction of 3a The solution of $\mathbf{3 a}(37 \mathrm{mg}, 0.124 \mathrm{mmol})$ in toluene $10 \mathrm{ml}$ was stirred at $-78^{\circ} \mathrm{C}$ for $10 \mathrm{~min}$ and then DIBAL $(0.3 \mathrm{ml}, 1 \mathrm{~mol} / \mathrm{l})$ was added to the cooled solution. After being stirred at the same temperature for $30 \mathrm{~min}$, the mixture was stirred for $24 \mathrm{~h}$ at room temperature. To the reaction mixture, $\mathrm{MeOH}(0.5 \mathrm{ml})$ was added and, after $30 \mathrm{~min}$, the mixture was filtered. The organic layer was concentrated in vacuo, and the residue was chromatographed on a column of silica-gel. The solvent of the fraction eluted with hexane-acetone $(4: 1)$ was evaporated to give cis-5,6,6a,7,10, 10a-hexahydro-6a-hydroxymethyl-5,8,9-trimethylphenanthridin-6-one $7 \mathrm{mg},(21 \%)]$.

4: Colorless columns (acetone-hexane), $\mathrm{mp} 128-130^{\circ} \mathrm{C}$. IR $(\mathrm{KBr}) \mathrm{cm}^{-1}$ : 3403, 1649, 1602. ${ }^{1} \mathrm{H}-\mathrm{NMR}\left(\mathrm{CDCl}_{3}\right) \delta: 1.59(3 \mathrm{H}, \mathrm{s}, \mathrm{Me}-\mathrm{C}), 1.63(3 \mathrm{H}, \mathrm{s}$ Me-C), $1.99(1 \mathrm{H}, \mathrm{d}, J=18.0 \mathrm{~Hz}, \mathrm{H}-7), 2.26-2.29(2 \mathrm{H}, \mathrm{br} \mathrm{m}, \mathrm{H}-10,10)$, $2.36(1 \mathrm{H}, \mathrm{d}, J=18.0 \mathrm{~Hz}, \mathrm{H}-7), 3.10(1 \mathrm{H}, \mathrm{dd}, J=6.6,6.6 \mathrm{~Hz}, \mathrm{H}-10 \mathrm{a}), 3.38$ $(3 \mathrm{H}, \mathrm{s}, \mathrm{Me}-\mathrm{N}), 3.62\left(1 \mathrm{H}, \mathrm{d}, J=6.5 \mathrm{~Hz}, \mathrm{CH}_{2}-\mathrm{O}\right), 3.66(1 \mathrm{H}, \mathrm{d}, J=6.5 \mathrm{~Hz}$, $\left.\mathrm{CH}_{2}-\mathrm{O}\right), 6.97-7.28\left(4 \mathrm{H}, \mathrm{m}, \mathrm{H}\right.$-aromatic). ${ }^{13} \mathrm{C}-\mathrm{NMR}\left(\mathrm{CDCl}_{3}\right) \delta: 18.8,18.9$, $30.0,32.7,33.0,35.5,46.0,65.6,114.5,122.5,123.4,124.2,126.6,127.4$, 128.5, 139.0, 173.2. MS m/z: $271\left(\mathrm{M}^{+}\right)$, 240, 189. Anal. Calcd for $\mathrm{C}_{17} \mathrm{H}_{21} \mathrm{NO}_{2}: \mathrm{C}, 75.24 ; \mathrm{H}, 7.80 ; \mathrm{N}, 5.16$. Found: $\mathrm{C}, 75.39 ; \mathrm{H}, 8.00 ; \mathrm{N}, 4.96$.

General Procedure for DA Cycloadditions of $1 a, b, e, f$ with $2 b$ a) The solution of $1 \mathbf{a}(217 \mathrm{mg}, 1 \mathrm{mmol})$ and $\mathbf{2 b}(860 \mathrm{mg}, 5 \mathrm{mmol})$ in $o$-xylene $(3 \mathrm{ml})$ was heated at $180^{\circ} \mathrm{C}$ for $4 \mathrm{~d}$ in a sealed tube. The reaction mixture was concentrated in vacuo and diluted with chloroform. To reaction mixture, TFA $(1 \mathrm{ml})$ was added with stirring at room temperature for $20 \mathrm{~min}$ and concentrated in vacuo. The residue was chromatographed on a column of silicagel. The solvent of the second fraction eluted with acetone-hexane $(1: 2)$ was evaporated. The crude product was purified by a preparative TLC over silica gel with ether-hexane $(4: 1)$ to give $c i s-5,6,6 \mathrm{a}, 7,8,10 \mathrm{a}$-hexahydro-10amethoxycarbonyl-5-methyl-6,9-dioxophenanthridine (6a). b) To the same reaction mixture, water $(2 \mathrm{ml})$ was added with stirring at room temperature for $20 \mathrm{~min}$. The chloroform layer was dried over $\mathrm{MgSO}_{4}$ and concentrated in vacuo. The residue was chromatographed on a column of silica-gel. The solvent of the second fraction eluted with acetone-hexane $(1: 2)$ was evaporated. The crude product was rechromatographed on a column of silica-gel with ether-hexane $(4: 1)$ to give $\mathbf{6 a}$ and cis-5,6,6a, 7,8,9,10,10a-octahydro-r10-methoxy-c-6a-methoxycarbonyl-5-methylphenanthridin-6,9-dione (7a). The second fraction gave cis-5,6,6a, 7,8,9,10,10a-octahydro-r-10-methoxy- $t$ 6a-methoxycarbonyl-5-methylphenanthrid-in-6,9-dione (8a). c) The reactions of $\mathbf{1 b}, \mathbf{e}(1 \mathrm{mmol})$ with $\mathbf{2} \mathbf{b}(5 \mathrm{mmol})$ were carried out under the conditions listed in Table 2 and the crude products were purified using the same procedure as described above to give cis-6a-cyano-5,6,6a,7,8,10a-hexahydro-5-methylphenanthridin-6,9-dione (6b), cis-6a-cyano-5,6,6a, 7,8,10ahexahydro-c-7-methoxy-5-methylphenanthridin-6,9-dione (7b), cis-6acyano-5,6,6a , 7,8,10a-hexahydro-t-methoxy-5-methylphenanthridin-6,9dione (8b), 3-(2,3-dihydro-4H-pyran-4-one-2-yl)-1-methyl-2( $1 H)$-quinolone (9), 9-hydroxy-5-methyl- phenanthridin-6-one (10a), respectively. The yields of $6 \mathbf{6}, \mathbf{b}, 7 \mathbf{a}, \mathbf{b} 8 \mathbf{a}, \mathbf{b}, \mathbf{9}$, and 10a are summarized in Table 2.

6a: Colorless columns, mp $136-138^{\circ} \mathrm{C}$ (acetone-ether). IR $(\mathrm{KBr}) \mathrm{cm}^{-1}$ : $1736,1686,1668,1603 .{ }^{1} \mathrm{H}-\mathrm{NMR}\left(\mathrm{CDCl}_{3}\right) \delta: 2.17-2.70(2 \mathrm{H}, \mathrm{m}, J=5.8$,
11.0, $\left.16.8 \mathrm{~Hz}, \mathrm{CH}_{2}\right), 3.45(3 \mathrm{H}, \mathrm{s}, \mathrm{Me}-\mathrm{N}), 3.67(3 \mathrm{H}, \mathrm{s}, \mathrm{COOMe}), 3.92(1 \mathrm{H}$, dd, $J=5.8,11.0 \mathrm{~Hz}, \mathrm{H}-10 \mathrm{a}), 6.22(1 \mathrm{H}, \mathrm{d}, J=10.2 \mathrm{~Hz}, \mathrm{H}-7), 7.05-7.36(5 \mathrm{H}$, $\mathrm{m}, \mathrm{H}-8$, aromatic). ${ }^{13} \mathrm{C}-\mathrm{NMR}\left(\mathrm{CDCl}_{3}\right) \delta: 30.3,40.5(\mathrm{C} 2), 53.5,55.5,115.4$, $124.2,125.0,127.6,128.8,130.3,138.5,145.3,165.3,170.0,195.4 . \mathrm{MS}$ m/z: $285\left(\mathrm{M}^{+}\right)$, 226. Anal. Calcd for $\mathrm{C}_{16} \mathrm{H}_{15} \mathrm{NO}_{4}: \mathrm{C}, 67.36 ; \mathrm{H}, 5.30 ; \mathrm{N}, 4.91$. Found: C, 67.58; H, 5.31; N, 4.64.

7a: Colorless columns, mp $155-157^{\circ} \mathrm{C}$ (acetone-hexane). IR (KBr) $\mathrm{cm}^{-1}: 1738,1717,1681,1605 .{ }^{1} \mathrm{H}-\mathrm{NMR}\left(\mathrm{CDCl}_{3}\right) \delta: 2.32(1 \mathrm{H}, \mathrm{d}$, $J=13.5 \mathrm{~Hz}, \mathrm{H}-10), 2.49(1 \mathrm{H}, \mathrm{dd}, J=13.5,5.1 \mathrm{~Hz}, \mathrm{H}-10), 2.82(2 \mathrm{H}, \mathrm{dd}$, $J=2.6,2.6 \mathrm{~Hz}, \mathrm{H}-8), 3.16(1 \mathrm{H}, \mathrm{dd}, J=4.3,15.5 \mathrm{~Hz}, \mathrm{H}-7), 3.35(3 \mathrm{H}, \mathrm{s}$, $\mathrm{Me}-\mathrm{O}), 3.45(3 \mathrm{H}, \mathrm{s}, \mathrm{Me}-\mathrm{N}), 3.61(3 \mathrm{H}, \mathrm{s}, \mathrm{COOMe}), 3.97(1 \mathrm{H}, \mathrm{dd}, J=5.1$, $13.5 \mathrm{~Hz}, \mathrm{H}-10 \mathrm{a}), 4.75(1 \mathrm{H}, \mathrm{dd}, J=2.6,2.6 \mathrm{~Hz}, \mathrm{H}-7), 7.00-7.31(4 \mathrm{H}, \mathrm{m}, \mathrm{H}-$ aromatic). ${ }^{13} \mathrm{C}-\mathrm{NMR}\left(\mathrm{CDCl}_{3}\right) \delta: 29.9,40.0,42.8,43.0,53.2,58.2,58.4$, $82.0,115.0,123.6,124.8,127.3,128.8,138.7,165.3,170.6,205.1$. MS $m / z$ : $317\left(\mathrm{M}^{+}\right)$. Anal. Calcd for $\mathrm{C}_{17} \mathrm{H}_{19} \mathrm{NO}_{5}: \mathrm{C}, 64.34 ; \mathrm{H}, 6.04 ; \mathrm{N}, 4.41$. Found: $\mathrm{C}$, 64.36; H, 6.04; N, 4.30. X-ray analytical data (Fig. 1): $2 \theta / \omega, 3^{\circ}<2 \theta<58^{\circ}$, $\mathrm{P} 2_{1} / c, \quad a=7.592(1), \quad b=27.043(4), \quad c=7.814(1) \AA, \quad \beta=105.59(1)^{\circ}, \quad V=$ $1545.2(3) \AA^{3}, Z=4, D_{\text {cacl }}=1.364 \mathrm{~g} / \mathrm{cm}^{3}, \mu(\mathrm{MoK \alpha})=0.94 \mathrm{~cm}^{-1} . R=0.051$ $\left(R_{\mathrm{w}}=0.052\right)$.

8a: Colorless columns, $\mathrm{mp} 202-203^{\circ} \mathrm{C}$ (acetone). IR (KBr) $\mathrm{cm}^{-1}: 1723$, $1673,1603 .{ }^{1} \mathrm{H}-\mathrm{NMR}\left(\mathrm{CDCl}_{3}\right) \delta: 2.46-2.56(2 \mathrm{H}, \mathrm{m}, \mathrm{H}-10,10), 2.88-3.10$ $(2 \mathrm{H}, \mathrm{m}, J=4.6,14.5 \mathrm{~Hz}, \mathrm{H}-8,8), 3.34(3 \mathrm{H}, \mathrm{s}, \mathrm{Me}-\mathrm{O}), 3.46(3 \mathrm{H}, \mathrm{s}, \mathrm{Me}-\mathrm{N})$, $3.47(1 \mathrm{H}, \mathrm{d}, J=7.0,10.2 \mathrm{~Hz}, \mathrm{H}-10 \mathrm{a}), 3.59(3 \mathrm{H}, \mathrm{s}, \mathrm{COOMe}), 4.00(1 \mathrm{H}, \mathrm{dd}$, $J=4.6,10.8 \mathrm{~Hz}, \mathrm{H}-7), 7.01-7.14(3 \mathrm{H}, \mathrm{m}, \mathrm{H}$-aromatic), 7.27-7.34 $(1 \mathrm{H}, \mathrm{m}$, $\mathrm{H}$-aromatic). ${ }^{13} \mathrm{C}-\mathrm{NMR}\left(\mathrm{CDCl}_{3}\right) \delta: 29.9,40.0,42.8,43.0,53.2,58.2,58.4$, $82.2,115.0,123.6,124.8,127.3,128.8,138.7,165.4,170.6,205.1$. MS $m / z$ : $317\left(\mathrm{M}^{+}\right)$. Anal. Calcd for $\mathrm{C}_{17} \mathrm{H}_{19} \mathrm{NO}_{5}: \mathrm{C}, 64.34 ; \mathrm{H}, 6.04 ; \mathrm{N}, 4.41$. Found: $\mathrm{C}$, 64.54; H, 6.16; N, 4.20 .

6b: Colorless columns (acetone-hexane), mp $156-158^{\circ} \mathrm{C}$. IR (KBr) $\mathrm{cm}^{-1}: 2242,1670,1606 .{ }^{1} \mathrm{H}-\mathrm{NMR}\left(\mathrm{CDCl}_{3}\right) \quad \delta: 2.61-2.82(2 \mathrm{H}, \mathrm{m}$, $J=5.0 \mathrm{~Hz}, \mathrm{H}-10,10), 3.49(3 \mathrm{H}, \mathrm{s}, \mathrm{Me}-\mathrm{N}), 3.85(1 \mathrm{H}, \mathrm{dd}, J=5.0,12.0 \mathrm{~Hz}, \mathrm{H}-$ 10a), $6.28(1 \mathrm{H}, \mathrm{d}, J=10.2 \mathrm{~Hz}, \mathrm{H}-8), 7.07(1 \mathrm{H}, \mathrm{d}, J=10.2 \mathrm{~Hz}, \mathrm{H}-7), 7.13-$ $7.46\left(4 \mathrm{H}, \mathrm{m}, \mathrm{H}\right.$-aromatic). ${ }^{13} \mathrm{C}-\mathrm{NMR}\left(\mathrm{CDCl}_{3}\right) \delta: 31.1,40.0,41.9,43.8$, $116.1,116.4,123.3,125.0,127.9,129.7,131.5,137.9$, 141.5, 161.1, 193.5. MS $m / z: 252\left(\mathrm{M}^{+}\right)$. Anal. Calcd $\mathrm{C}_{15} \mathrm{H}_{12} \mathrm{~N}_{2} \mathrm{O}_{2}: \mathrm{C}, 71.41 ; \mathrm{H}, 4.80 ; \mathrm{N}, 11.11$. Found: C, 71.18; H, 5.00; N, 10.98 .

7b: Colorless columns (acetone-hexane), mp 196-198 ${ }^{\circ} \mathrm{C}$. IR (KBr) $\mathrm{cm}^{-1}: 2241,1725,1675,1606 .{ }^{1} \mathrm{H}-\mathrm{NMR}\left(\mathrm{CDCl}_{3}\right) \delta: 2.20(1 \mathrm{H}, \mathrm{dd}, J=13.2$, $15.2 \mathrm{~Hz}, \mathrm{H}-8), 2.54$ (1H, dd, $J=5.3,15.2 \mathrm{~Hz}, \mathrm{H}-8), 2.79$ (2H, m, H-10, 10), $3.51(3 \mathrm{H}, \mathrm{s}, \mathrm{Me}-\mathrm{N}), 3.54(3 \mathrm{H}, \mathrm{s}, \mathrm{Me}-\mathrm{O}), 3.83(1 \mathrm{H}, \mathrm{dd}, J=5.3,13.2 \mathrm{~Hz}, \mathrm{H}-$ $10 \mathrm{a}), 4.59(1 \mathrm{H}, \mathrm{dd}, J=6.3,6.3 \mathrm{~Hz}, \mathrm{H}-7), 7.14-7.26(3 \mathrm{H}, \mathrm{m}, \mathrm{H}$-aromatic), 7.38-7.44 (1H, m, H-aromatic). ${ }^{13} \mathrm{C}-\mathrm{NMR}\left(\mathrm{CDCl}_{3}\right) \delta: 30.8,39.6,41.2$, 43.3, 47.2, 58.2, 79.1, 116.0, 116.7, 124.7, 125.0, 128.1, 129.5, 137.5, 161.4, 204.0. MS m/z: $284\left(\mathrm{M}^{+}\right)$, 184. Anal. Calcd for $\mathrm{C}_{16} \mathrm{H}_{16} \mathrm{~N}_{2} \mathrm{O}_{3}: \mathrm{C}, 67.59 ; \mathrm{H}$, 5.67; N, 9.85. Found: C, 67.34; H, 5.86; N, 9.76.

8b: Colorless columns (acetone-hexane), mp $229-230^{\circ} \mathrm{C}$. IR $(\mathrm{KBr})$ $\mathrm{cm}^{-1}: 2245,1726,1690,1603 .{ }^{1} \mathrm{H}-\mathrm{NMR}\left(\mathrm{CDCl}_{3}\right) \delta: 2.86(2 \mathrm{H}, \mathrm{d}, J=6.6 \mathrm{~Hz}$, $\mathrm{H}-10,10), 2.93$ ( $2 \mathrm{H}, \mathrm{br} \mathrm{m}, \mathrm{H}-8,8), 3.28$ ( $3 \mathrm{H}, \mathrm{s}, \mathrm{Me}-\mathrm{N}), 3.48$ (3H, s, Me-O), $3.74(1 \mathrm{H}, \mathrm{dd}, J=6.6,6.6 \mathrm{~Hz}, \mathrm{H}-10 \mathrm{a}), 4.13(1 \mathrm{H}, \mathrm{dd}, J=6.6,6.6 \mathrm{~Hz}, \mathrm{H}-7)$, $7.04-7.38$ (4H, m, H-aromatic). ${ }^{13} \mathrm{C}-\mathrm{NMR}\left(\mathrm{CDCl}_{3}\right) \delta: 30.9,40.0,40.7$, 42.9, 48.4, 59.0, 82.5, 115.1, 117.6, 123.6, 124.4, 126.3, 129.0, 138.5, 162.1, 203.0. MS m/z: $284\left(\mathrm{M}^{+}\right), 184$. Anal. Calcd for $\mathrm{C}_{16} \mathrm{H}_{16} \mathrm{~N}_{2} \mathrm{O}_{3}: \mathrm{C}, 67.59 ; \mathrm{H}$, 5.67; N, 9.85. Found: C, 67.33; H, 5.89; N, 9.83

9: Yellow columns (acetone-hexane), $\mathrm{mp} 154^{\circ} \mathrm{C}$. IR $(\mathrm{KBr}) \mathrm{cm}^{-1}: 1651$, 1626, 1592. ${ }^{1} \mathrm{H}-\mathrm{NMR}\left(\mathrm{CDCl}_{3}\right) \delta: 2.69\left(1 \mathrm{H}, \mathrm{dd}, J=13.5,16.5 \mathrm{~Hz}, \mathrm{H}-3^{\prime}\right), 3.03$ $\left(1 \mathrm{H}, \mathrm{ddd}, J=1.2,3.5,16.5 \mathrm{~Hz}, \mathrm{H}-3^{\prime}\right), 3.76(3 \mathrm{H}, \mathrm{s}, \mathrm{Me}-\mathrm{N}), 5.55(1 \mathrm{H}, \mathrm{dd}$, $\left.J=1.2,6.1 \mathrm{~Hz}, \mathrm{H}-5^{\prime}\right), 5.75\left(1 \mathrm{H}, \mathrm{dd}, J=3.5,13.5 \mathrm{~Hz}, \mathrm{H}-2^{\prime}\right), 7.29(1 \mathrm{H}, \mathrm{ddd}$, $J=1.0,7.4,7.4 \mathrm{~Hz}, \mathrm{H}-6), 7.39(1 \mathrm{H}, \mathrm{dd}, J=1.0,9.2 \mathrm{~Hz}, \mathrm{H}-8), 7.30(1 \mathrm{H}, \mathrm{d}$, $\left.J=6.1 \mathrm{~Hz}, \mathrm{H}-6^{\prime}\right), 7.58-7.64(2 \mathrm{H}, \mathrm{m}, \mathrm{H}-5,7) .{ }^{13} \mathrm{C}-\mathrm{NMR}\left(\mathrm{CDCl}_{3}\right) \delta: 29.7$, $41.4,76.8,107.81,114.2,119.9,122.6,129.2,129.8,131.0,135.1,139.5$, 160.2, 162.8, 191.9. MS m/z: $255\left(\mathrm{M}^{+}\right), 227,198,184$. HR-MS m/z: Calcd for $\mathrm{C}_{15} \mathrm{H}_{13} \mathrm{NO}_{3}\left(\mathrm{M}^{+}\right)$: 255.0895. Found: 255.0861. Anal. Calcd for $\mathrm{C}_{15} \mathrm{H}_{13} \mathrm{NO}_{3}$ : C, 70.58; H, 5.13; N, 5.49. Found: $\mathrm{C}, 70.31 ; \mathrm{H}, 5.02 ; \mathrm{N}, 5.31$.

10a: Yellow plates (chloroform), $\mathrm{mp} 297-300^{\circ} \mathrm{C}$. IR $(\mathrm{KBr}) \mathrm{cm}^{-1}: 3607$, 1625, 1604. ${ }^{1} \mathrm{H}-\mathrm{NMR}\left(\mathrm{CDCl}_{3}\right) \delta: 3.89(3 \mathrm{H}, \mathrm{s}, \mathrm{Me}-\mathrm{N}), 7.06(1 \mathrm{H}, \mathrm{dd}, J=2.5$, $8.9 \mathrm{~Hz}, \mathrm{H}-8), 7.41(1 \mathrm{H}, \mathrm{ddd}, J=1.2,7.1,8.4 \mathrm{~Hz}, \mathrm{H}-2), 7.51(1 \mathrm{H}, \mathrm{dd}, J=1.2$, $8.6 \mathrm{~Hz}, \mathrm{H}-4), 7.62(1 \mathrm{H}, \mathrm{d}, J=2.5 \mathrm{~Hz}, \mathrm{H}-10), 7.63(1 \mathrm{H}, \mathrm{ddd}, J=1.5,7.1$, $8.6 \mathrm{~Hz}, \mathrm{H}-3), 8.15(1 \mathrm{H}, \mathrm{dd}, J=1.5,8.4 \mathrm{~Hz}, \mathrm{H}-1), 8.34(1 \mathrm{H}, \mathrm{d}, J=8.9 \mathrm{~Hz}, \mathrm{H}-$ 7), $9.89(1 \mathrm{H}, \mathrm{brs}, \mathrm{OH}) .{ }^{13} \mathrm{C}-\mathrm{NMR}\left(\mathrm{CDCl}_{3}\right) \delta: 31.2,106.8,116.1,117.6$, 119.7, 120.7, 123.6, 124.2, 130.5, 136.6, 136.9, 159.6, 160.1. MS m/z: 225 $\left(\mathrm{M}^{+}\right)$, 196. HR-MS $m / z$ : Calcd for $\mathrm{C}_{14} \mathrm{H}_{11} \mathrm{NO}_{2}, 225.0790$. Found: 225.0753 .

General Procedure for HP-DA Cycloadditions of 1a, b with 2a, b a) A mixture of 1a, b $(0.5 \mathrm{mmol})$ and $\mathbf{2 a}(205 \mathrm{mg}, 2.5 \mathrm{mmol})$ in dichloromethane $(3 \mathrm{ml})$ was placed in a Teflon tube, and reacted under conditions 
listed in Table 1. The crude products were purified using the same procedure as described above to give $\mathbf{3 a}, \mathbf{b} . \mathbf{b})$ A mixture of $\mathbf{1 a}(108 \mathrm{mg}, 0.5 \mathrm{mmol})$ and 2b $(430 \mathrm{mg}, 2.5 \mathrm{mmol})$ in dichloromethane $(3 \mathrm{ml})$ was placed in a Teflon tube. The tube was placed in a high pressure reactor and pressurized to 10 $\mathrm{kbar}$, followed by heating at $90^{\circ} \mathrm{C}$ for $48 \mathrm{~h}$. The pressure was released and the reaction mixture was purified using the same procedure as described above to give $6 \mathbf{a}$ and $8 \mathbf{a}$. A mixture of $\mathbf{1 b}$ with $\mathbf{2 b}$ was reacted under conditions listed in Table 2 and the crude products were purified using the same procedure as described above to give $\mathbf{6 b}, \mathbf{7} \mathbf{b}$ and $\mathbf{8 b}$. The yields of $\mathbf{3 a}, \mathbf{b}$, $\mathbf{6 a}, \mathbf{b}, 7 \mathbf{a}, \mathbf{b}$ and $8 \mathbf{8}, \mathbf{b}$ are summarized in Tables 1 and 2 .

Demethanolation of $7 \mathbf{a}, \mathbf{b}$ and $8 \mathbf{8}, \mathbf{b}$ a) The solution of $7 \mathbf{a}(25 \mathrm{mg}$, $0.08 \mathrm{mmol}$ ) and $1 \mathrm{ml}$ TFA in $10 \mathrm{ml}$ chloroform was refluxed for $4 \mathrm{~h}$ and concentrated in vacuo. The residue was purified by preparative TLC over silicagel with ether-isopropyl ether $(1: 3)$ to give $\mathbf{6 a}(22 \mathrm{mg}$, 97\%). The same reaction mixture of $8 \mathbf{a}(25 \mathrm{mg}, 0.08 \mathrm{mmol})$ was refluxed for $9 \mathrm{~h}$ using the same procedure as described above to give 6a (22 mg, 97\%). b) Demethanolation of $7 \mathbf{b}$ or $\mathbf{8 b}(28 \mathrm{mg}, 0.08 \mathrm{mmol})$ was stirred at room temperature for $96 \mathrm{~h}$ using the same procedure as described above to give $6 \mathbf{b}(20 \mathrm{mg}, 79 \%$; $17 \mathrm{mg}, 68 \%)$, respectively. c) The solution of $7 \mathrm{a}(20 \mathrm{mg}, 0.064 \mathrm{mmol})$ in $3 \mathrm{ml} o$-xylene was heated at $180^{\circ} \mathrm{C}$ for $3 \mathrm{~d}$ and purified using the same procedure as described above to give $\mathbf{6 a}(14 \mathrm{mg}, 78 \%)$.

Calculation of Activation Energy We optimized the structures of the initial and the transition states using the restricted Hartree-Fock (RHF) method at $\mathrm{HF} / 6-31++\mathrm{G}(d, p) / / \mathrm{HF} / 6-31 \mathrm{G}(d)$ level in the Gaussian 98 program package. ${ }^{12)}$ The effect of the solvent was not considered. Assuming that the diene and the dienophile were far apart at the initial state, we calculated the activation energy $(E a)$ as a difference in energy between the TS and the initial state. After optimizing the TS structure, we performed the vibrational calculation and confirmed that the TS had exactly one imaginary vibrational frequency. We also carried out the intrinsic reaction coordinate (IRC) calculation to make sure that the TS connects the initial with the intended final state.

\section{References and Notes}

1) a) Cook D. J., Bower R. E., Sorter P., Daniels E., J. Org. Chem., 26, 4949-4955 (1961); b) Tomisawa H., Watanabe M., Fujita R., Hongo H., Chem. Pharm. Bull., 18, 919-924 (1970); c) Tomisawa H., Kobayashi Y., Hongo H., Fujita R., ibid., 18, 923-936 (1970); d) Tomisawa H., Fujita R., Hongo H., Kato H., ibid., 22, 2091-2096 (1974); e) Tomisawa H., Fujita R., Hongo H., ibid., 23, 592-596 (1975); f) Nishiwaki N., Tanaka A., Uchida M., Tohda Y., Ariga M., Bull. Chem. Soc. Jpn., 69, 1377-1381 (1996); g) Nishiwaki N.,
Tanaka C., Asahara M., Asaka N., Tohda Y., Ariga M., Heterocycles, 51, 567-574 (1999); h) Micheline G.-D., Alan M., Synthetic Comm., 25, 2999-3006 (1995).

2) Nagata T., Koide Y., Nara K., Itoh E., Arisawa M., Naruto S., Torisawa Y., Hino T., Nakagawa M., Chem. Pharm. Bull., 44, 451— 453 (1996).

3) For biological properties of phenanthridine alkaloids, see: Rigby J. H., Holsworth D. D., James K., J. Org. Chem., 54, 4019-4020 (1989); Narasimhan N. S., Chandrachood P. S., Tetrahedron, 37, 825-827 (1981); T. Okamoto, Y.Torri, Y.Isogai, Chem. Pharm. Bull., 16, 1860-1864 (1968); Mondon A., Krohn K., Chem. Ber., 108, 445468 (1975).

4) Fujita R., Watanabe K., Yoshisuji T., Matsuzaki H., Harigaya Y., Hongo H., Chem. Pharm. Bull., 49, 407-412 (2001).

5) Matsumoto K., Sera A., Uchida T., Synthesis, 1985, 1-26; Matsumoto K., Sera A., ibid., 1985, 999-1027.

6) Moustaid K., Nguyen D. A., Vebrel J., Loude B., Daou B., Soufiaoui M., C. R. Academie Sci., Ser. II Univers., 312, 1129-1133 (1991).

7) Raj T. T., Amberker S. Y., J. Prakt. Chem., 330, 293-298 (1988); Junek H., Wilfinger W., Monatshefte fur Chemie, 101, 112-1129 (1970).

8) Fernandez M., Cuesta E. de la, Avendano C., Synthesis, 1995, 13621364.

9) Mittasch A., J. Prakt. Chem., 68, 103-105 (1903); Kaneko C., Chem. Pharm. Bull., 7, 273-277 (1959).

10) Trost B. M., "Comprehensive Organic Synthesis," Vol. 2, Pergamon Press, Oxford, 1991, pp. 661-706.

11) Mopac 2000, Stewart J. J. P., Fujitsu Limited, Tokyo, Japan, 1999; Stewart J. J. P., J. Comp. Chem., 10, 209-220 (1989); idem, ibid., 10, 221-264 (1989).

12) Gaussian 98, Revision A.9, Frisch M. J., Trucks G. W., Schlegel H. B., Scuseria G. E., Robb M. A., Cheeseman J. R., Zakrzewski V. G., Montgomery J. A., Jr., Stratmann R. E., Burant J. C., Dapprich S., Millam J. M., Daniels A. D., Kudin K. N., Strain M. C., Farkas O., Tomasi J., Barone V., Cossi M., Cammi R., Mennucci B., Pomelli C., Adamo C., Clifford S., Ochterski J., Petersson G. A., Ayala P. Y., Cui Q., Morokuma K., Malick D. K., Rabuck A. D., Raghavachari K., Foresman J. B., Cioslowski J., Ortiz J. V., Baboul A. G., Stefanov B. B., Liu G., Liashenko A., Piskorz P., Komaromi I., Gomperts R., Martin R. L., Fox D. J., Keith T., Al-Laham M. A., Peng C. Y., Nanayakkara A., Challacombe M., Gill P. M. W., Johnson B., Chen W., Wong M. W., Andres J. L., Gonzalez C., Head-Gordon M., Replogle E. S., Pople J. A., Gaussian, Inc., Pittsburgh PA, 1998. 